\title{
LANDSLIDE HAZARD ZONATION AROUND GILGEL GIBE-II HYDROELECTRIC PROJECT, SOUTHWESTERN ETHIOPIA
}

\author{
Engdawork Mulatu 1, Tarun Kumar Raghuvanshi ${ }^{2, *}$ and Bekele Abebe ${ }^{2}$ \\ ${ }^{1}$ Gilgel-Gibe II Hydroelectric Project, Fofa Town, Ethiopia Email: engdawork2001@yahoo.com \\ ${ }^{2}$ Department of Earth Sciences, Faculty of Science, Addis Ababa University, PO Box 1176 \\ Addis Ababa, Ethiopia. E-mail: tarunraghuvanshi@yahoo.com or babebe@geol.aau.edu.et
}

\begin{abstract}
The present study was carried out along the newly constructed road from Fofa town to Gilgel Gibe-II powerhouse in South western Ethiopia. In this study, an attempt has been made to provide information on the landslide hazard zones present along the new road. In order to delineate the hazardous zones the landslide hazard evaluation factor rating scheme (LHEF) proposed by Anbalagan (1992) has been utilized. The LHEF rating scheme is based on an empirical approach which combines past experience gained from the study of causative factors and their impact on landslides with conditions anticipated in the area of study. For LHEF rating scheme data on major inherent causative factors of slope instability such as geology, slope morphometry, relative relief, land use and land cover and ground water conditions has been collected. Based on the evaluation values, the slopes in the study area have been classified for landslide potential as; High Hazard, Moderate Hazard and Low Hazard. The results of the present study indicate that $54 \%$ of the slopes in the study area fall in High Hazard, $34 \%$ in the Moderate Hazard and $12 \%$ in the Low Hazard zones. Thus, the Landslide Hazard Zonation shows that chances of slope failures are high in the study area.
\end{abstract}

Key words/phrases: Hazard zonation, landslide, landslide hazard evaluation, slope instability

\section{INTRODUCTION}

A $30 \mathrm{~km}$ long road, from Fofa town to Gilgel GibeII powerhouse has been constructed in South western Ethiopia. This road is the only access to the Gilgel Gibe-II hydropower project, which is one of the major hydropower Projects coming up in Ethiopia. In order to provide a safe access to the hydropower project, the safe functioning of this road is very important. The road alignment passes mainly through extremely rugged terrain, characterized by steep hill slopes and deep valleys. The present study has been carried out to provide information on the landslide hazard zones along this new road section.

The study area lies in the Yem Zone of the Southern Nations Nationalities and Peoples Regional State (SNNPRS) west of the central Main Ethiopian Rift and is bounded by Oromia Regional State and by Gibe River in the western and eastern sides, respectively. The project area can be accessed from Addis Ababa by road to Fofa town, which is about $280 \mathrm{~km}$ on Addis Ababa- Jimma road. It is bounded between $7^{\circ} 45^{\prime}$ to $7^{\circ} 52^{\prime} \mathrm{N}$ latitude and $37^{\circ} 30^{\prime}$ to $37^{\circ} 35^{\prime} \mathrm{E}$ longitude and falls within the Omo-Gibe River Basin (Fig. 1).

The area is extremely rugged and the variation in the elevation is very large. The maximum elevation in the project area is about $2640 \mathrm{~m}$ near
Fofa town and the minimum elevation is $920 \mathrm{~m}$, at the bed of Gibe River. The study area is bounded in the eastern side by a major escarpment along the Gibe River, which has similar orientation with main Ethiopian rift system to the east. At the higher elevations, relative relief is moderate $(101 \mathrm{~m}$ to $300 \mathrm{~m}$ ). Out of the total study area, around $75 \%$ falls in high relative relief, which is more than 300 $\mathrm{m}$.

The drainage pattern of the project area is almost a rectangular type and most of the tributary streams are aligned parallel to structural weaknesses which parallel the Gojeb graben south of the study area. The major tributaries of Gibe River are Derbu and Kora streams, and are seasonal in nature.

The precipitation and temperature data for the period 1989-2004, for Sekoru station have been collected from National Meteorological Service Agency. The climate of the area is semi-arid with daily average temperature variation between $12^{\circ} \mathrm{C}$ to $28^{\circ} \mathrm{C}$. The highest monthly precipitation recorded was $314 \mathrm{~mm}$ in July 1996. However, the minimum monthly rainfall of $15.7 \mathrm{~mm}$ has been recorded in the month of December. There is only one distinct rainy season (from June to August) for which the annual average precipitation is $1320 \mathrm{~mm}$ (EEPCO, 2004).

\footnotetext{
* Author to whom all correspondence should be addressed.
} 


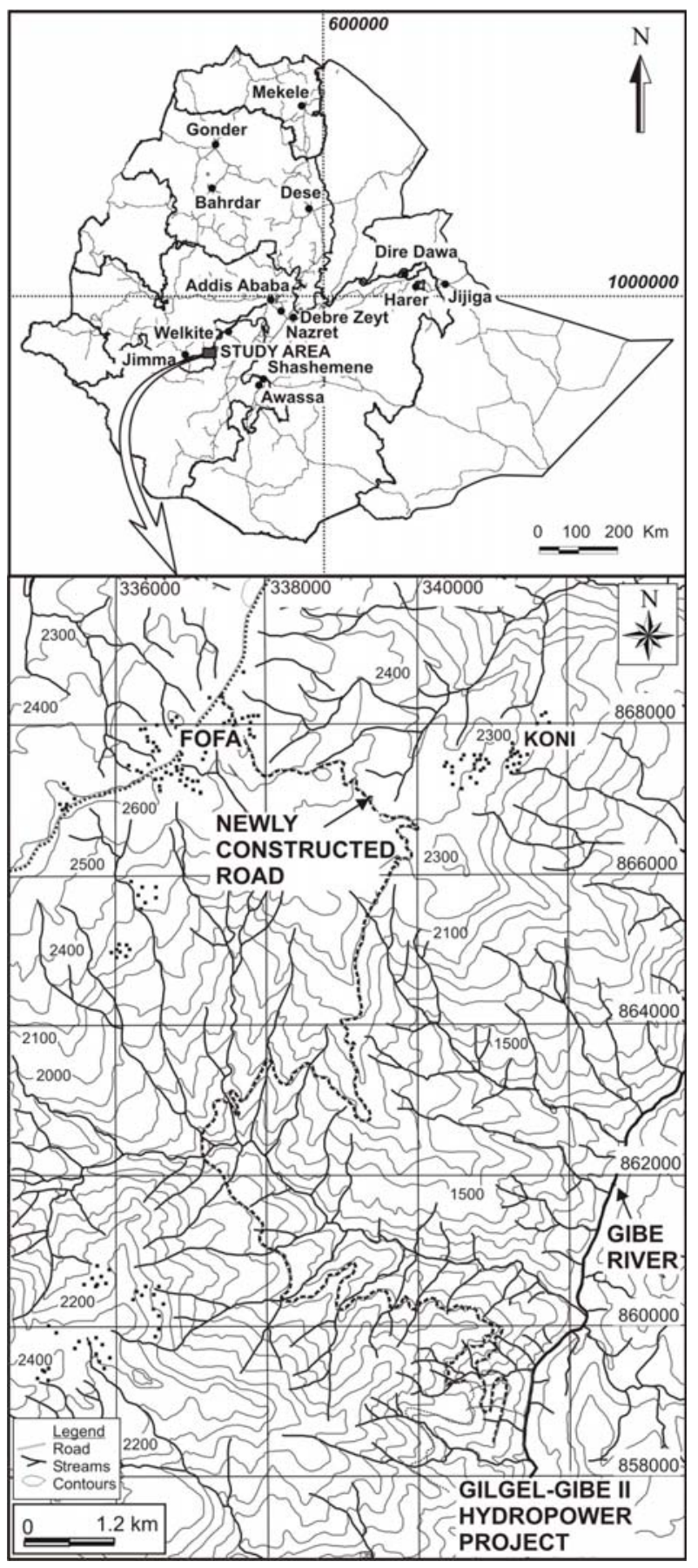

Fig. 1. Location map of the study area.

\section{PREVIOUS WORKS}

Landslide activity is very common particularly in the Highlands of Ethiopia. In the northern, western and southern highlands of Ethiopia the resulting damage due to landslides has been increasing due to various natural and man-made factors. Several studies have been conducted following various qualitative, analytical and empirical approaches to assess the causes and factors that trigger landslides in different parts of the highlands of the country. However, in the present study area no published or unpublished study on landslides has been reported. A brief description of various studies on landslides in Ethiopia is presented in following paragraphs.

Shiferaw Ayele (2009) utilized Remote sensing and GIS approach to delineate Landslide Hazard zones in Abay Gorge (Gohatsion-Dejen), Central Ethiopia. The various causative factors considered for this study were, geology, groundwater condition, drainage, slope, structures, aspect and land use/ land cover. In this study, comparison of the landslide hazard map was made with actual landslide events of the study area and found that $67 \%$ landslides lie within the maximum hazard zone delineated by the study.

Henok Woldegiorgis (2008) made landslide hazard zonation mapping in southern part of Blue Nile Gorge using a Land Hazard Evaluation Factor (LHEF) to characterize the Landslide Hazard potential in the study area. By utilizing the limit equilibrium method, he further made quantitative analysis for critical slopes.

Jemal Saed (2005) conducted slope stability studies on the road section between Gohatsion and Dejen towns. He made the quantitative analysis of critical slope sections following limit equilibrium method.

Yodit Teferi (2005) carried out a research on Evaluation of Land Degradation and Landslide Using Integrated GIS and Remote Sensing approach around Sodo-Shone Area, Southern Ethiopia. This research suggests two types of mass movements, flow and rock fall in the area. Mud flow was induced by intensive rainfall and observed in gently sloping areas.

Tenalem Ayenew and Barbieri (2004) made landslide studies and susceptibility mapping in the Dessie area. According to this study, four broad landslide susceptibility zones and 22 specific active landslide sites were identified. The findings of this study suggests that in the study area the most important landslide types were complex earth and debris slides and flows in silty clay soils associated with alluvial and colluvial deposits overlying highly weathered basalts.

Lulseged Ayalew and Yamagishi (2002) studied land sliding and Landscape Development in Northern Ethiopia. Findings of this research show nine types of slopes based on concavity and convexity of horizontal and vertical profiles; the type of landslides sheltered in these slopes were sorted out and explained. The significant contributions of landslides to landscape develop- 
ment were discussed and the principal phases of landscape evolutions were determined.

Berhanu Temesigen et al. (2001) conducted a research on landslide in the Wondo-Genet area. In this research, evaluation of the occurrences of landslides and their relationships with various event controlling parameters was made using GIS and Remote Sensing techniques.

Getachew Lemmesa et al. (2000) conducted mass movement hazard assessment in Betto, Goffa district, North Omo Zone, Southern Ethiopia. The study identified that the main cause of landslide was the existence of old landslides on steep slopes that was covered by deeply weathered, closely jointed or sheared basaltic rocks.

Similar landslide or slope stability studies were carried out by Lulseged Ayalew (1999), Kefeyalew Terefe (2001), Gebretsidik Eshete (1982), Mesfin Wubshet et al. (1994), Almaz Gezahegn and Tadesse Dessie (1994), etc.

\section{GEOLOGY}

The study area is found in Omo-Gibe river basin, which is one of the largest basins in South-western Ethiopia. The regional geology of the Omo-Gibe river basin comprises of Precambrian crystalline basement, Eocene to Miocene volcanic rocks, Quaternary lacustrine deposits, alluvial sediments and volcanic flows (Davidson and Rex, 1983).

A large tract of land stretching from south of Weliso to Welkite-Hosaina-Sodo and Selam Ber and the adjacent plateau west of Omo river is underlain by a sequence of trachyte, rhyolite, ignimbrite and tuff with minor intercalated basalt flows and lacustrine sediments (Tiercelin et al., 1980; Kazmin and Seife Michael Berhe, 1978). The Jimma volcanics form a thick succession of basalts and rhyolites underlying the Nazreth group in the area. The rhyolites conformably lie over the basalts and are equivalent to Magdala Group. The entire volcanic succession rests on the Precambrian Basement, the unconformity being marked by basal residual sandstone. Dykes and sills excessively intrude the Jimma rhyolite.

The geology of the study area is dominated by Nazreth Group rocks. A poorly welded rhyolitic tuff is the youngest unit in the study area and is found at higher elevations. This unit comprises white and reddish tuffs, the latter being apparently the parent material for the red clay soil and is well exposed near Fofa town. Minor intercalations of trachytic rocks also occur in the rhyolite (Fig. 2).

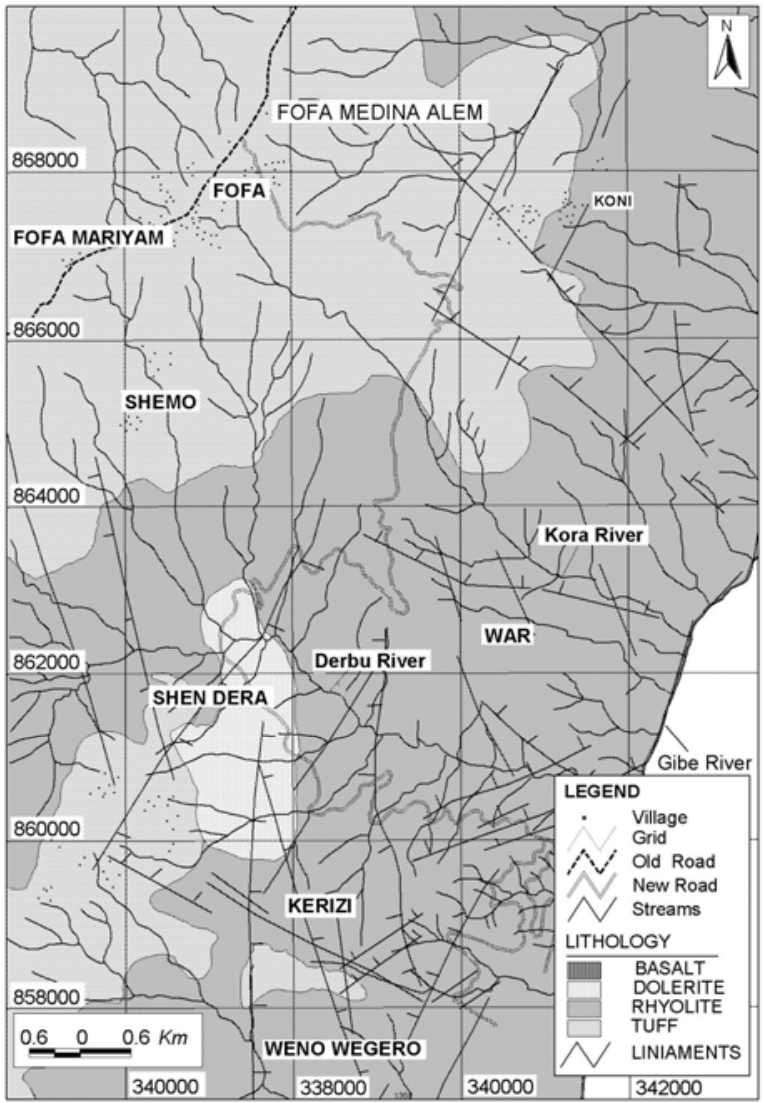

Fig. 2. Geology of the study area.

Dolerite dykes and sills and syenite intrusions have also been observed in the area. The dolerite rocks vary from dark grey, coarse-grained to fine grained greenish colour. The fracture spacing in most doleritic rocks ranges from $10-50 \mathrm{~cm}$, as observed in the borehole logs (EEPCO, 2004). Thin irregular calcite stringers are also found along planes of weaknesses.

The central part of Omo-Gibe basin is cut by a series of East-West trending, 2.5-12 km wide and 20-30 km long shallow grabens. These basins are occupied by recent alluvial deposits. A similar graben also occurs in the lower reaches of Gojeb river, in the southern part of the study area. The upper reaches of the Gojeb River follow one of these structures. Major northeast-southwest trending lineaments and subordinate north-west oriented lineaments are observed.

\section{LANDSLIDE HAZARD ZONATION}

For landslide hazard zonation, different researchers apply different schemes based on different causative factors. According to Bieniawiski (1989) for the case of slope cut and 
underground mining activities, the schemes for hazard or failure zones identification have been developing for over 100 years since Ritter (1879) attempted to formalize an empirical approach to tunnel design, particularly for the determination of support requirements. While the classification schemes are appropriate for their original application, especially, if used within the bounds of the case histories from which they were developed, considerable caution must be exercised in applying rock mass classifications to other rock engineering problems. Different classification systems place different emphases on the various parameters. Most of the multi-parameter classification schemes were developed from civil engineering case histories in which all of the components of the engineering geological character of rock mass were included (Bieniawiski, 1989).

Biniawiski (1989) also states that Terzaghi (1946) classified rock mass, based on those characteristics that dominate rock mass behaviour, particularly in situations where gravity constitutes the dominant driving force. He gave clear and concise definitions for the terms like, intact rock, stratified rock, moderately jointed, blocky and seamy, crushed rock, squeezing and swelling rock. Terzaghi's classification is site-specific and qualitative technique which is time consuming and more subjective. This is more applicable for underground structures and less applicable for natural slopes.

As stated by Bieniawiski (1989), Wickham et al., (1972) described a quantitative method for describing the quality of a rock mass and for selecting appropriate support on the basis of their Rock Structure Rating (RSR) classification. The significance of the RSR system is that it introduces the concept of rating on each of the three components, geology, geometry and effect of groundwater inflow on joint condition. The RSR system includes three parameters; (a) Geology which includes origin of rock type, rock hardness and geologic structures (b) Effect of discontinuity pattern with respect to joint spacing, orientation and direction of tunnel drive, and (c) Effect of groundwater inflow and joint condition on the basis of overall rock mass quality based on geology and effect of groundwater inflow, joint condition (good, fair, poor) and amount of water inflow. Based on the observations on the three parameters, ratings from standard tables are assigned and sum of ratings of the three parameters give a numeric RSR value. Thus, based on this RSR value, rock mass characterization can be worked out which may lead to estimation of support determination. Though the merit of RSR technique is that numerical ratings can be assigned for various parameters, this technique is site-specific and less applicable for natural slopes.

Bieniawski (1989) introduced a rock mass classification system called the Geomechanics Classification or the Rock Mass Rating (RMR) system. In applying this classification system, the rock mass is divided into a number of structural regions and each region is classified, separately. The RMR system requires, assigning rating for each of the six parameters like: Uniaxial compressive strength of rock material (UCS), Rock Quality Designation (RQD), Spacing of discontinuities, Condition of discontinuities, Groundwater conditions and Orientation of discontinuities. The sum of these ratings gives the RMR, based on which the quality of rock mass can be defined. Further, RMR may also be utilized to determine the shear strength parameters of the rock mass and the deformability character of the rock mass.

Barton et al. (1974) proposed a Tunnelling Quality Index $(Q)$ for the determination of rock mass characteristics and tunnel support requirements on the basis of an evaluation of a large number of case histories of underground excavations. They use six parameters and gave rating for each parameter. These parameters are the rock quality designation, joint set number, joint roughness number, joint alteration number, joint water reduction factor and stress reduction factor.

Romana (1985) introduced slope Mass Rating (SMR) as an application of Rock mass Rating (RMR) of Beniawski (1979). It takes into consideration the parameters such as attitudes of discontinuities, disposition of slope failure modes as well as slope excavation methods. Anbalagan et al. (1992) modified the approach of Romana (1985) and generalized it to incorporate wedge mode of failure.

RMR and SMR systems can be utilized to characterize the rock mass strength and stability condition of rock slopes. Both methods are applied for specific zones of excavation or natural slopes. This may need more time and money to apply for studies covering large areas like landslide hazard zonation mapping. Considering these limitations for stability studies, "Landslide Hazard Evaluation Factor Rating Scheme" (LHEF) of Anbalagan (1992) is selected for the present study because of its advantage to handle different causative factors for evaluating landslide hazard easily and quickly. LHEF scheme can cover large area of study by considering the most important geological factors 
and rating them based on their influence on landslide.

\section{LANDSLIDE HAZARD EVALUATION FACTOR (LHEF) RATING SCHEME}

Anbalagan's (1992) LHEF Scheme is a numerical rating system and is based on inherent causative factors of slope instability such as geology, slope morphometry, relative relief, land use and land cover and groundwater conditions. In order to delineate the landslide hazard in a given area, landslide hazard zonation (LHZ) mapping technique is employed. LHZ is a macro- zonation technique for which maps are generally prepared on 1:25000 to 1:50000 scales. The general methodology for LHZ mapping includes desk study and field investigation. During the desk study pre-field maps are prepared for which aerial photographs, satellite imageries topographic maps and geological maps are utilized. These maps are prepared for lithological, structural, slope morphometry, relative relief, rock outcrop and soil cover, and land use land cover. The desk study helps to plan and execute the field investigation systematically. The various maps prepared for different causative factors during desk study can be verified and modified during field investigation.

During field study information is gathered Facet wise. Facet is the land use which has more or less similar characteristics of slope showing consistent slope direction and inclination. The maximum LHEF ratings for various causative factors are assigned on the basis of their contribution for instability. Table 1 shows the proposed maximum LHEF rating for different contributory factors for macro-zonation (Anbalagan, 1992).

Table 1. Proposed maximum LHEF rating for different contributory factors for macro-zonation (after Anbalagan, 1992)

\begin{tabular}{ll}
\hline Contributory Factor & Maximum LHEF Rating \\
\hline Lithology & 2.0 \\
Relationship of structural & 2.0 \\
discontinuity with slope & 2.0 \\
Slope morphometry & 1.0 \\
Relative relief & 2.0 \\
Land use and land cover & 1.0 \\
Ground water condition & 10.0 \\
Total & \\
\hline
\end{tabular}

Further, the net probability of instability is determined by the total estimated hazard (TEHD). This TEHD is determined facet wise for which observations and investigations are made during field work and accordingly ratings are assigned from the standard tables. The sum total of LHEF ratings for various causative factors, facet wise, will give the TEHD.

$$
\begin{aligned}
\text { TEHD }= & \text { Ratings of (lithology }+ \text { structure }+ \text { slope } \\
& \text { morphometry }+ \text { relative relief }+ \text { land use and } \\
& \text { land cover }+ \text { groundwater conditions })
\end{aligned}
$$

\section{Field data collection and analysis}

For the present study the entire study area was divided into 125 slope facets (Fig. 3). Facet is defined as a land unit which is characterized by more or less uniform slope geometry in terms of slope inclination and slope direction (Sharma, 2006). For the present study topographical maps were utilized to demarcate the facets. Facet boundaries were delineated by major or minor hills and ridges, primary and secondary streams and other topographical undulations. The facet map, thus prepared, has been later utilized as a base map for the collection of data/ information on various causative factors. According to Anbalagan (1992), the various causative factors which contribute for the instability of slopes are lithology, relationship of structural discontinuity with slope, slope morphometry, relative relief, land use and land cover and surface traces of groundwater. Thus, all these causative factors form the basis of LHEF rating scheme.

The total maximum LHEF rating assigned for various causative factors is 10 . Out of which lithology, relationship of structural discontinuities with slope, slope morphometry and land use and land cover contribute a maximum LHEF rating of 2.0 each, whereas relative relief and groundwater conditions contributes maximum LHEF rating of 1.0 each. These ratings have been assigned based on the significance and relative contribution of each causative factor on stability condition. The sum total of LHEF ratings for all causative factors gives the total estimated hazard (TEHD). The larger the TEHD value, the higher degree of Hazard. Table 2 presents the landslide hazard zonation on the basis of TEHD.

Table 2. Landslide Hazard zonation on the basis of Total Estimated Hazard (TEHD) (after Anbalagan, 1992).

\begin{tabular}{lll}
\hline Zone & TEHD Value & Description of Zone \\
\hline I & $<3.5$ & Very Low Hazard (VLH) \\
II & $3.5-5.0$ & Low Hazard $(\mathrm{LH})$ \\
III & $5.1-6.0$ & Moderate hazard $(\mathrm{MH})$ \\
IV & $6.1-7.5$ & High Hazard $(\mathrm{HH})$ \\
V & $>7.5$ & Very High Hazard $(\mathrm{VHH})$ \\
\hline
\end{tabular}




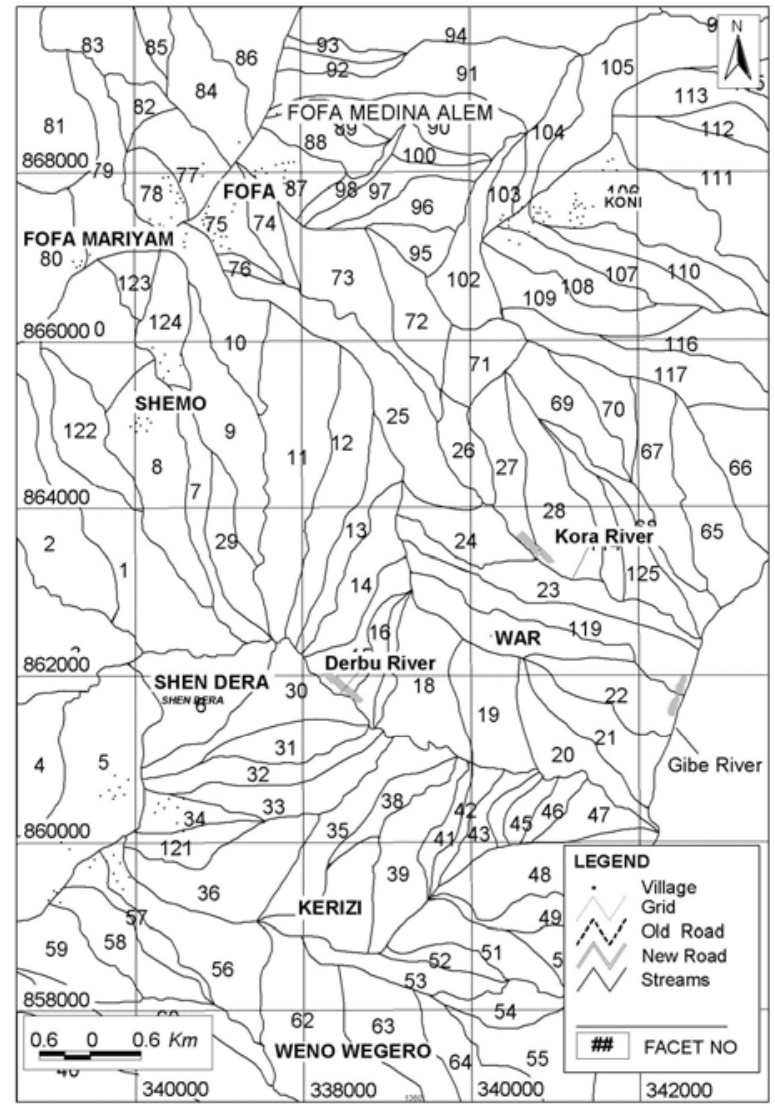

Fig. 3. Facet map of the study area.

For the present study data pertaining to these causative factors were collected from the field. Further, these data on various causative factors were analyzed facet wise and numerical ratings from the LHEF standard tables were assigned. The detailed description on these causative factors is discussed in the following paragraphs.

\section{Lithology}

The lithological and structural setting of the area is presented on the geological map (Fig. 2). The main criterion in awarding the ratings for subcategories of lithology is the response of the rocks to the processes of weathering and erosion. The degree of weathering may vary from rock to rock. For example, rocks like quartzite, limestone and igneous rocks are generally hard, massive and resistant to erosion, thus form steep slopes. Terrigenous sedimentary rocks are more vulnerable to weathering and may easily contribute to landslides. Similarly, rocks like schists and phyllites are characterized by flaky minerals which make them more prone to weathering and thus, promote instability. Therefore, lower ratings are assigned for hard rocks (e.g., quartzite and limestone - rating 0.2) and more ratings are assigned for softer rocks (e.g., shale, phyllites and schist - rating 2.0). Furthermore, an additional correction factor for degree of weathering of rocks has also been provided in LHEF scheme (Anbalagan, 1992).

For soils, genesis and age are the main criteria in awarding the ratings. Older alluvium is generally well compacted and has a high shearing resistance (rating 0.8) thus, will demonstrate stable condition. Recent materials such as slide debris are loose and have low shearing resistance (rating 2.0). Thus, the soils which posses high shearing resistance have been assigned low ratings whereas soils with low shearing strength has been assigned high ratings (Anbalagan, 1992).

In the present study area, four major lithological units are found. These are rhyolite, tuff, dolerite and basalts (Fig. 2). Out of these, the dominant rock units which constitute the slopes in the study area are rhyolite, tuff and dolerite. Accordingly, rating for the rhyolite and dolerite unit is considered as 0.3 , tuff unit is considered as soil because it is highly weathered and poorly compacted. Accordingly, rating of 1.0 is assigned from the standard LHEF table.

\section{Relationship of structural discontinuity with slope}

In rocks, primary and secondary discontinuities are present in the form of bedding, joints, foliation and faults. The preferred orientations of these discontinuities with respect to slope inclination have great influence on the slope instability. The following three relations are important as far as slope stability is concerned:

(i) The degree of parallelism between the directions of the discontinuities, or the line of intersection of two discontinuities and the slope.

(ii) The dip of the discontinuity, or the plunge of the line of intersection of two discontinuities.

(iii) The difference in the dip of the discontinuity, or the plunge of the line of intersection of the two discontinuities and the inclination of the slope.

The risk of failure becomes greater when the discontinuity or the line of intersection of two discontinuities tends to be parallel to the slope. Such condition may lead to satisfying a kinematic condition for rock mass failure. When the dip of the discontinuity or plunge of the line of intersection of two discontinuities increases, the probability of failure also increases, thus higher ratings are assigned. Further, if the dip of the 
discontinuity plane or the plunge of the line of intersection of the two discontinuities does not exceed the slope inclination, the failure potential remains high. Thus, the LHEF ratings for relationship of structural discontinuity with slope have been assigned for various stability conditions on the basis of the approach indicated by Romana (1985) and Anbalagan (1992). However, for soils the inferred depth of the soil cover is the main criterion for awarding the ratings.

In the study area, the structures used are mainly joints and fault planes. Facet wise the structural data have been collected and plotted on a stereonet for their preferred orientation in relation with slope faces of each facet, later respective ratings have been awarded from the standard LHEF table.

\section{Slope morphometry}

On the basis of the frequency of occurrence of particular angles of slope, morphometry defines the various categories of slopes. The classification into slope morphometry categories is dependent on various factors such as; geomorphological history of the area. The angle of slope of each unit is a reflection of a series of localized processes and controls, which have been imposed on the facet. The slope morphometry map has been prepared by dividing the larger topographical map into smaller map used to create the slope units. The contour lines have the same standard spacing. There are six categories representing the slopes: escarpment/cliff $\left(>40^{\circ}\right)$, steep slope $\left(35^{\circ}-40^{\circ}\right)$, moderately steep slope $\left(25^{\circ}-35^{\circ}\right)$, gentle slope $\left(15^{\circ}\right.$ $\left.25^{\circ}\right)$ and very gentle slope $\left(<15^{\circ}\right)$. For steeper slopes higher ratings are assigned as steep slopes are more prone to instability (Anbalagan, 1992).

In the study area, most of the escarpments are concentrated along Derbu River (Fig. 4). However, moderately steep slopes are extensively found in the central part, whereas the area near Fofa is classified as gentle slope $\left(<15^{\circ}\right)$.

\section{Relative relief}

The relative relief is defined as the elevation difference between the ridge top and the valley floor within an individual facet. For hazard evaluation purposes, three categories of slopes of relative relief have been selected; these are, low $(<$ $100 \mathrm{~m})$, medium $(101-300 \mathrm{~m})$ and high $(>300 \mathrm{~m})$. Pachauri and Pant (1991) described that landslide potential is greatest in the areas of high relief. In areas of higher relief, gravity sliding and debris flow have been more commonly observed. Higher relative relief indicates more instability conditions in comparison to Low relative relief areas.
Accordingly higher LHEF rating has been assigned to areas where relative relief is high. (Anbalagan, 1992).

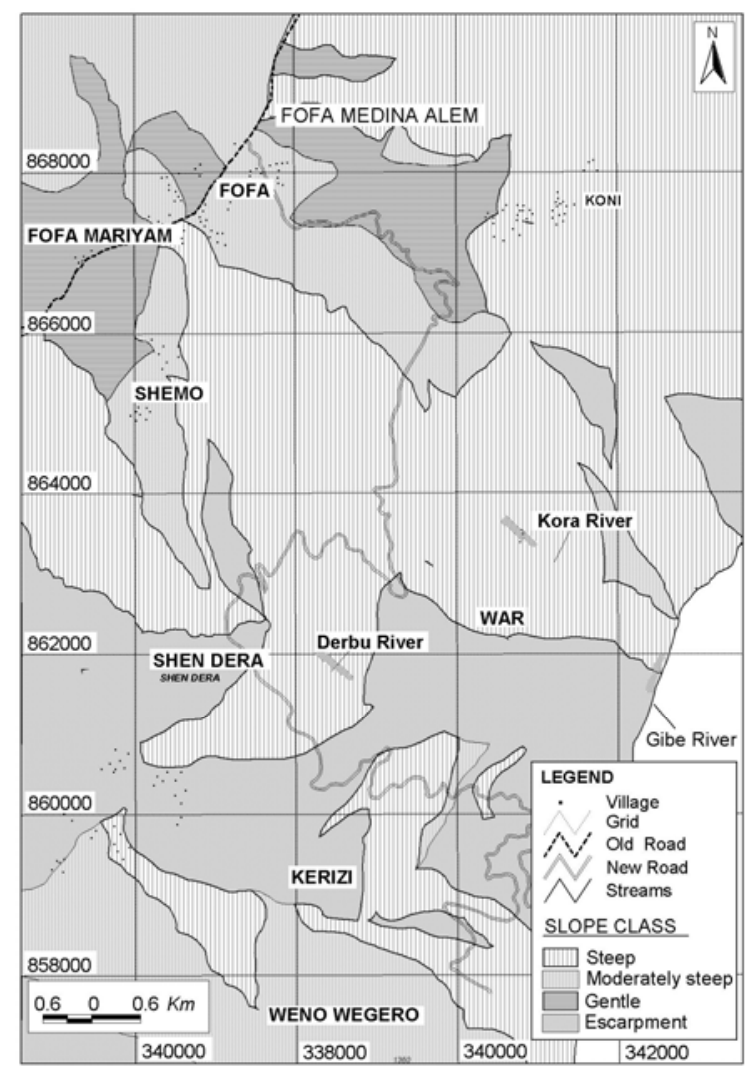

Fig. 4. Slope Morphometry Map of the study area.

In the present study area, more than $85 \%$ of the project area has high relative relief $(>300 \mathrm{~m})$; therefore, the chances of slope instability are quite high (Fig. 5).

\section{Land use and land cover}

Land cover may also describe potential for instability of slopes. Sparsely vegetated areas and barren areas demonstrate more erosion, thus greater instability as compared to reserve or protected forests, which are thickly vegetated and are less prone to mass wasting processes. Furthermore, forest cover, in general minimizes the effect of climatic agents on the slope faces and protects from weathering and erosion. A wellspread root system of plants also increases the shearing resistance of slope material. The agricultural lands represent areas of repeated water charging for cultivation purposes and as such may be considered stable since agricultural practices are made on relatively gentler slopes. Thus, barren lands are assigned maximum LHEF ratings (2.0) as these are more prone for instability in comparison to vegetated areas (Anbalagan, 1992). 


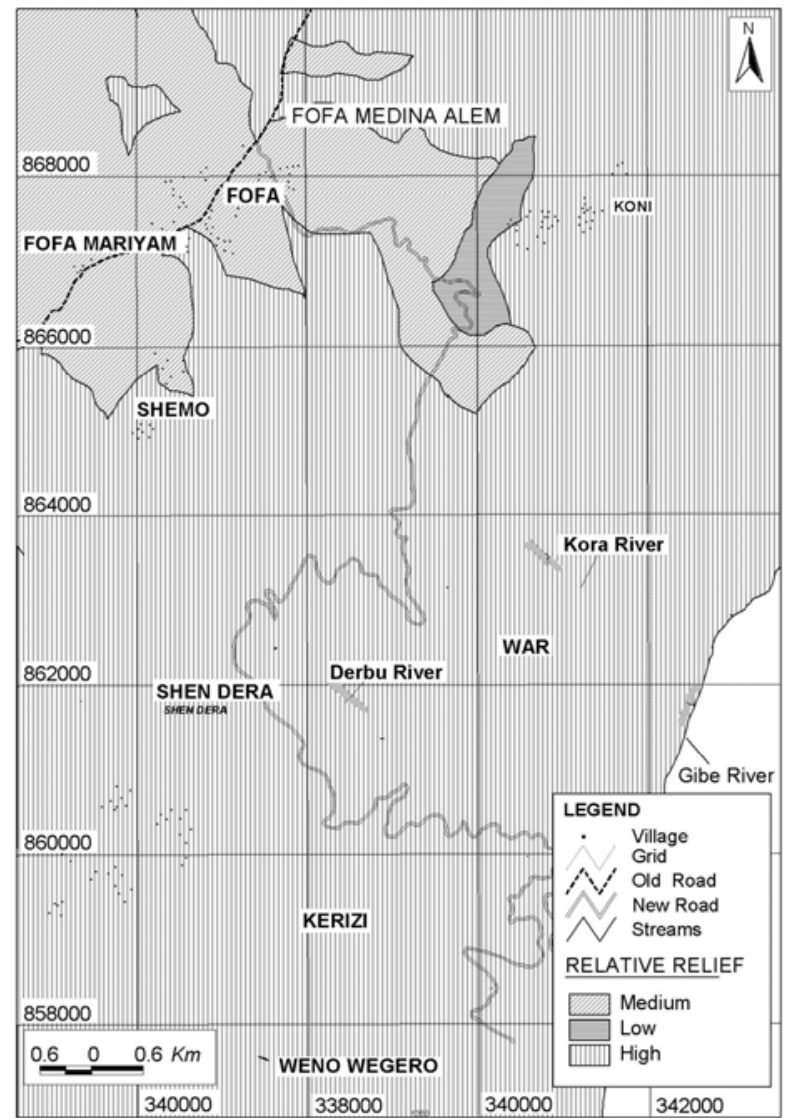

Fig. 5. Relative relief of the study area.

In the present case, based on the criteria of intensity of vegetation cover, the ratings have been awarded. The area is highly rugged and most of the land is classified as steep slope. None of the area falls in the flat agricultural land. However, few isolated pockets of flat land are present near Fofa town which is being utilized for house construction (Fig. 6). Most of the agricultural plots in the area are on the moderately steep slopes and rarely in the steep ones. There are few isolated clusters of dense forest covers in the project area. The vegetation cover along the river banks is comparatively good consisting of desert shrubs and bushes.

\section{Groundwater condition}

Groundwater has a major influence on slope stability. The groundwater in hilly terrains does not have a uniform pattern and is generally channelled along structural discontinuities in rocks. The assessment of groundwater behaviour in hilly terrains over large areas is difficult and time consuming. Therefore, for a quick appraisal, the groundwater behaviour is assessed based on surface indications of groundwater which may provide valuable information on the stability of hill slopes for hazard mapping purposes. Surface indications of water such as damp, wet, dripping, and flowing are used for rating purposes. Accordingly, ratings were assigned for surface traces of groundwater as: flowing (1.0), Dripping (0.8), Wet (0.5), Damp (0.2) and Dry (0.0). The observations taken after the rainy season provide probably the possible worst groundwater conditions (Anbalagan, 1992).

The present field work was carried out during the dry season and the surface water condition was almost dry throughout the study area, except at very few places like the major rivers and near Fofa town where surface water was observed.

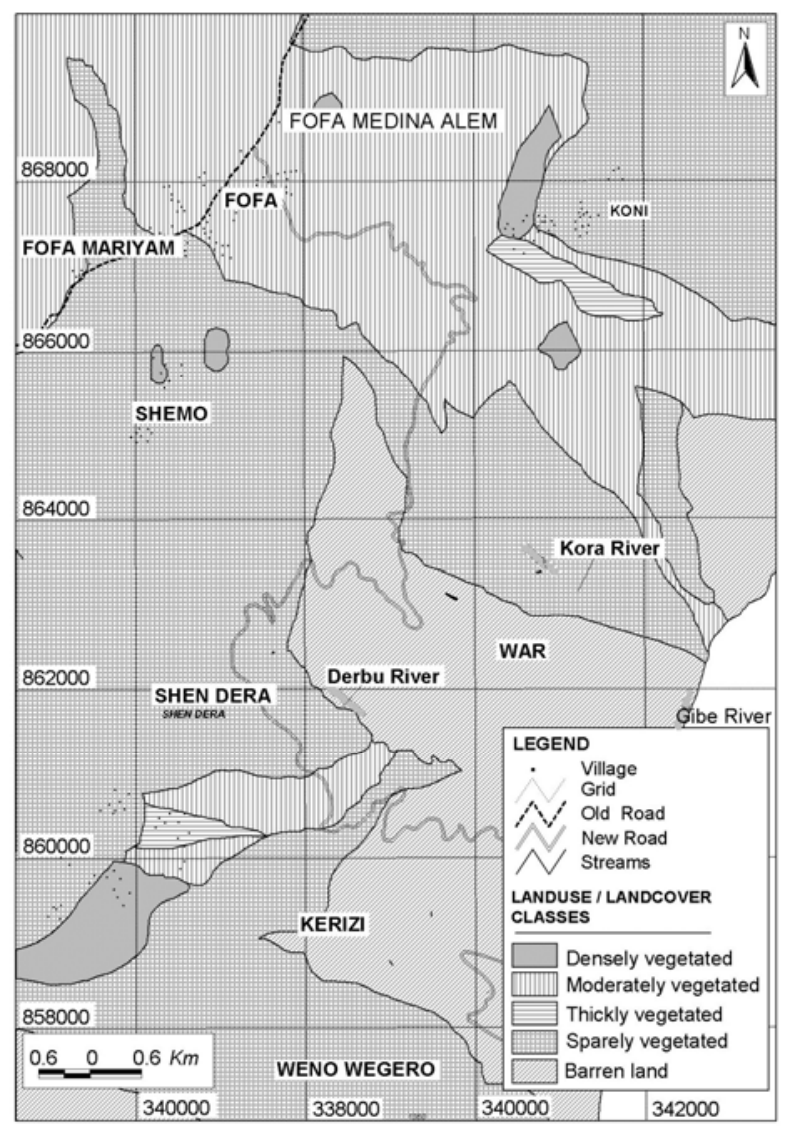

Fig. 6. Land use and Land cover in the study area.

\section{LANDSLIDE HAZARD EVALUATION IN THE STUDY AREA}

There are several Classification systems for Landslide Hazard Evaluation based on ranking. In order to prepare a landslide hazard map on the basis of different causative factors, as described in previous section, it is necessary to quantify the land using a weighting and rating system. All qualitative classes require a ranking method by 
which each class can be quantified and weighting given to each factor to create a landslide hazard rank. The logical assumption is that the risk of occurrence of a damaging event or landslide is a direct consequence of these parameters. Therefore, these parameters can be given due weighting resulting in weighted landslide hazard values for each subclass. Each parameter is given a weighting depending on its degree of affiliation to the landslide hazard (Fall et al., 2006).

The process and exact mechanisms involved in landslides are difficult to assess. This makes prediction quite difficult. Therefore, there is a substantial degree of uncertainty involved in any hazard evaluation process.

On the basis of TEHD, there may be five categories of landslide hazard zones, namely, very low hazard (VLH < 3.5), low hazard (LH -3.5 to 5.0), moderate hazard (MH -5.1 to 6.0), high hazard (HH - 6.1 to 7.5 ) and very high hazard ( $\mathrm{VHH}>7.5$ ). In the present study, after evaluating TEHD, it is found that there are only three classes: low hazard, moderate hazard and high hazard. The two opposite extremes namely, very low hazard and very high hazard are not present in the study area. Table 3 presents the TEHD facet wise ratings for the study area. The ratings assigned for each causative factor are based on the observations made on individual facets in the field.

\section{Low hazard}

According to Anbalagan, (1992) low hazard zone has a TEHD value between 3.5 and 5.0. Out of a total of 125 facets in the study area, 18 fall within low hazard zone. These are relatively flat or low relief areas located in the northern part of the project area around Fofa. This zone covers $12 \%$ of the total area and comprises mainly very weak rhyolitic tuff deposits (Fig. 7).

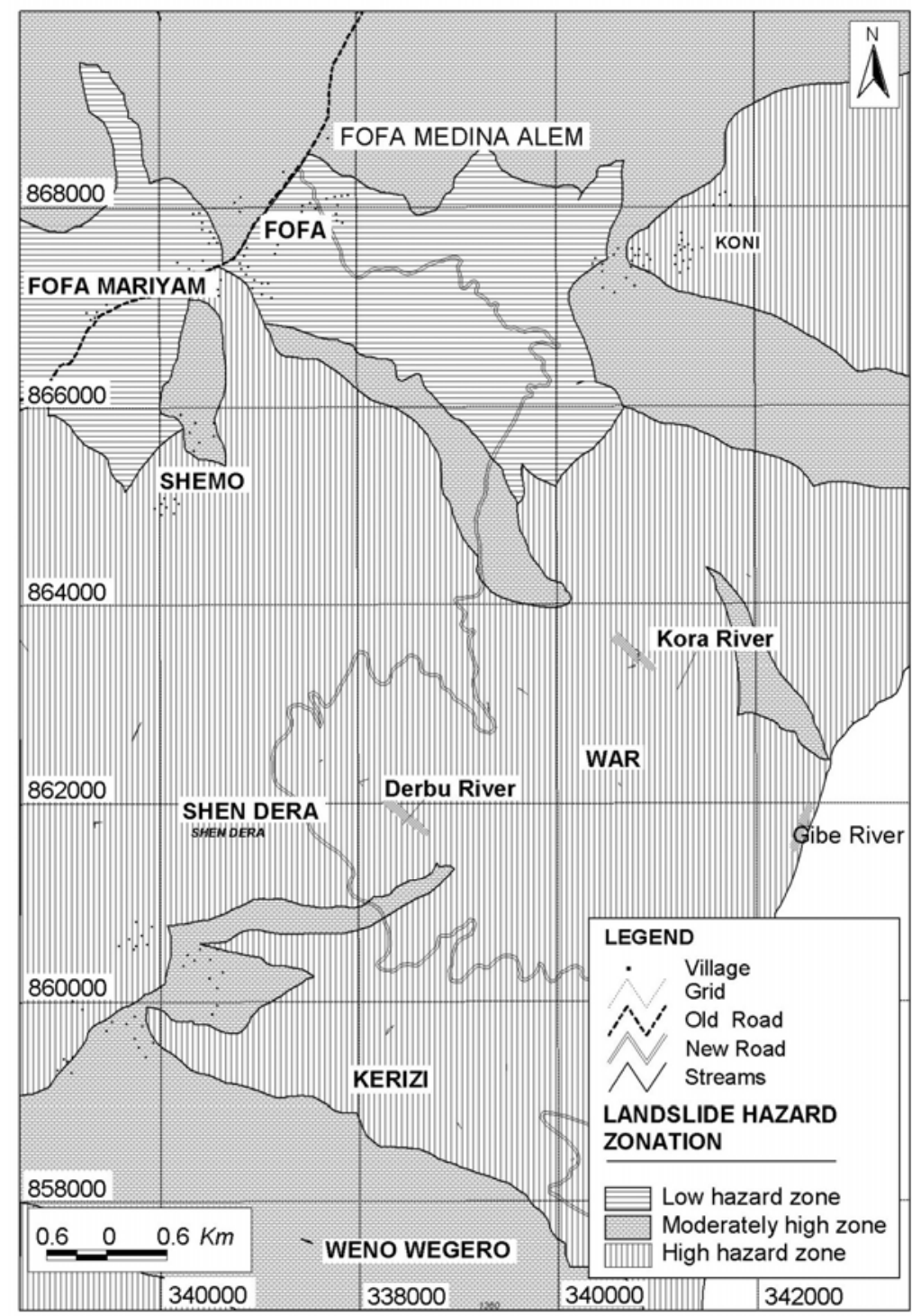

Fig. 7. Landslide Hazard Zonation of the study area. 
Table 3. Facet wise TEHD ratings for the study area.

\begin{tabular}{|c|c|c|c|c|c|c|c|c|c|c|c|c|c|c|c|c|c|}
\hline $\begin{array}{l}0 \\
Z \\
\ddot{U} \\
\tilde{U} \\
\end{array}$ & 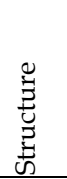 & 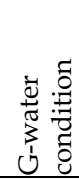 & $\begin{array}{l}\overrightarrow{00} \\
\frac{0}{0} \\
0 \\
0 \\
0\end{array}$ & 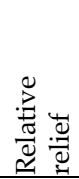 & 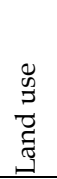 & 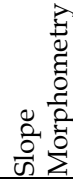 & 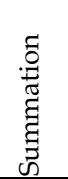 & $\stackrel{*}{*}$ & 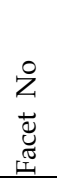 & 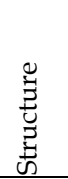 & 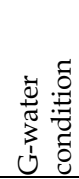 & $\begin{array}{l}\overrightarrow{00} \\
0 \\
0 \\
0 \\
0 \\
0\end{array}$ & 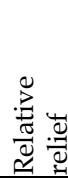 & 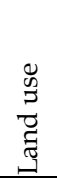 & 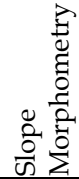 & 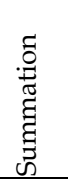 & $\stackrel{\text { 毁 }}{*}$ \\
\hline$\overline{1}$ & 1.6 & 0 & 1 & 1 & 1.5 & 1.7 & 6.8 & $\mathrm{HH}$ & 43 & 0.95 & 0 & 0.9 & 1 & 2 & 2 & 6.85 & $\mathrm{HH}$ \\
\hline 2 & 1.6 & 0 & 1 & 1 & 1.5 & 1.7 & 6.8 & $\mathrm{HH}$ & 44 & 1.2 & 0 & 0.9 & 1 & 2 & 1.7 & 6.8 & $\mathrm{HH}$ \\
\hline 3 & 1.6 & 0 & 1 & 1 & 1.5 & 2 & 7.1 & $\mathrm{HH}$ & 45 & 0.7 & 0 & 0.9 & 1 & 2 & 2 & 6.6 & $\mathrm{HH}$ \\
\hline 4 & 1.6 & 0 & 1 & 1 & 1.5 & 2 & 7.1 & $\mathrm{HH}$ & 46 & 1.3 & 0 & 0.9 & 1 & 2 & 2 & 7.2 & $\mathrm{HH}$ \\
\hline 5 & 1.6 & 0 & 1 & 1 & 1.5 & 2 & 7.1 & $\mathrm{HH}$ & 50 & 1.2 & 0 & 0.9 & 1 & 2 & 2 & 7.1 & $\mathrm{HH}$ \\
\hline 6 & 1.6 & 0 & 0.9 & 1 & 1.7 & 2 & 7.2 & $\mathrm{HH}$ & 51 & 1.3 & 0 & 0.9 & 1 & 2 & 1.7 & 6.9 & $\mathrm{HH}$ \\
\hline 7 & 1.5 & 0 & 0.9 & 1 & 1.5 & 1.7 & 6.6 & $\mathrm{HH}$ & 52 & 1.3 & 0 & 0.9 & 1 & 2 & 2 & 7.2 & $\mathrm{HH}$ \\
\hline 8 & 1.6 & 0 & 0.9 & 1 & 1.5 & 1.2 & 6.2 & $\mathrm{HH}$ & 53 & 1.3 & 0 & 0.9 & 1 & 2 & 1.7 & 6.9 & $\mathrm{HH}$ \\
\hline 9 & 1.5 & 0 & 0.9 & 1 & 1.5 & 1.7 & 6.6 & $\mathrm{HH}$ & 54 & 1.1 & 0 & 0.9 & 1 & 2 & 1.7 & 6.7 & $\mathrm{HH}$ \\
\hline 10 & 1.5 & 0 & 0.9 & 1 & 1.5 & 1.7 & 6.6 & $\mathrm{HH}$ & 55 & 0.8 & 0 & 0.9 & 1 & 2 & 1.7 & 6.4 & $\mathrm{HH}$ \\
\hline 11 & 1.5 & 0 & 0.9 & 1 & 1.5 & 1.7 & 6.6 & $\mathrm{HH}$ & 56 & 0.7 & 0 & 0.9 & 1 & 1.5 & 1.7 & 5.8 & $\mathrm{MH}$ \\
\hline 12 & 1.5 & 0 & 0.9 & 1 & 2 & 1.7 & 7.1 & $\mathrm{HH}$ & 57 & 0.7 & 0 & 0.9 & 1 & 1.5 & 1.2 & 5.3 & $\mathrm{MH}$ \\
\hline 13 & 1.5 & 0 & 0.9 & 1 & 2 & 1.7 & 7.1 & $\mathrm{HH}$ & 58 & 0.7 & 0 & 0.9 & 1 & 1.5 & 1.2 & 5.3 & $\mathrm{MH}$ \\
\hline 14 & 1.2 & 0 & 0.9 & 1 & 2 & 1.7 & 6.8 & $\mathrm{HH}$ & 59 & 0.7 & 0 & 0.9 & 1 & 1.5 & 1.2 & 5.3 & $\mathrm{MH}$ \\
\hline 15 & 1.2 & 0 & 0.9 & 1 & 2 & 1.7 & 6.8 & $\mathrm{HH}$ & 60 & 0.7 & 0 & 0.9 & 1 & 1.5 & 1.2 & 5.3 & $\mathrm{MH}$ \\
\hline 16 & 1.2 & 0.2 & 0.9 & 1 & 2 & 1.7 & 7 & $\mathrm{HH}$ & 61 & 0.7 & 0 & 0.9 & 1 & 1.5 & 1.2 & 5.3 & $\mathrm{MH}$ \\
\hline 17 & 1.2 & 0.2 & 0.9 & 1 & 2 & 2 & 7.3 & $\mathrm{HH}$ & 62 & 0.7 & 0 & 0.9 & 1 & 1.5 & 1.2 & 5.3 & $\mathrm{MH}$ \\
\hline 18 & 1 & 0 & 0.9 & 1 & 2 & 2 & 6.9 & $\mathrm{HH}$ & 63 & 0.7 & 0 & 0.9 & 1 & 1.5 & 1.2 & 5.3 & MH \\
\hline 19 & 1 & 0 & 0.9 & 1 & 2 & 2 & 6.9 & $\mathrm{HH}$ & 64 & 0.7 & 0 & 0.9 & 1 & 1.5 & 1.2 & 5.3 & $\mathrm{MH}$ \\
\hline 20 & 1 & 0 & 0.9 & 1 & 2 & 2 & 6.9 & $\mathrm{HH}$ & 65 & 1.3 & 0 & 0.9 & 1 & 2 & 1.7 & 6.9 & $\mathrm{HH}$ \\
\hline 21 & 1 & 0 & 0.9 & 1 & 2 & 2 & 6.9 & $\mathrm{HH}$ & 66 & 1.3 & 0 & 0.9 & 1 & 2 & 2 & 7.2 & $\mathrm{HH}$ \\
\hline 22 & 1 & 0 & 0.9 & 1 & 2 & 2 & 6.9 & $\mathrm{HH}$ & 67 & 1.3 & 0 & 0.9 & 1 & 1.5 & 1.7 & 6.4 & $\mathrm{HH}$ \\
\hline 23 & 1 & 0 & 0.9 & 1 & 1.5 & 1.7 & 6.1 & $\mathrm{HH}$ & 68 & 1.3 & 0 & 0.9 & 1 & 1.3 & 1.7 & 6.2 & $\mathrm{HH}$ \\
\hline 24 & 1.1 & 0 & 0.9 & 1 & 1.5 & 1.7 & 6.2 & $\mathrm{HH}$ & 69 & 1.3 & 0 & 0.9 & 1 & 1.3 & 1.7 & 6.2 & $\mathrm{HH}$ \\
\hline 25 & 0.7 & 0.2 & 0.9 & 1 & 1.5 & 1.7 & 6 & $\mathrm{MH}$ & 70 & 1.3 & 0 & 0.9 & 1 & 1 & 2 & 6.2 & $\mathrm{HH}$ \\
\hline 26 & 1 & 0 & 0.9 & 1 & 1.5 & 1.7 & 6.1 & $\mathrm{HH}$ & 71 & 1 & 0 & 0.9 & 0.6 & 1.2 & 1.2 & 4.9 & LH \\
\hline 27 & 1 & 0.2 & 0.9 & 1 & 1.5 & 1.7 & 6.3 & $\mathrm{HH}$ & 72 & 0.7 & 0 & 0.9 & 0.6 & 1.2 & 1.2 & 4.6 & LH \\
\hline 28 & 1 & 0.2 & 0.9 & 1 & 1.5 & 1.7 & 6.3 & $\mathrm{HH}$ & 73 & 0.7 & 0 & 0.9 & 1 & 1.2 & 1.2 & 5 & LH \\
\hline 29 & 1.5 & 0 & 0.9 & 1 & 1.5 & 2 & 6.9 & $\mathrm{HH}$ & 74 & 0.85 & 0 & 1 & 0.6 & 1.2 & 1.2 & 4.85 & LH \\
\hline 30 & 1 & 0 & 0.9 & 1 & 1.5 & 1.7 & 6.1 & $\mathrm{HH}$ & 75 & 0.85 & 0 & 1 & 0.6 & 1.2 & 1.2 & 4.85 & LH \\
\hline 31 & 1.05 & 0 & 0.9 & 1 & 1.5 & 1.7 & 6.15 & $\mathrm{HH}$ & 77 & 0.85 & 0.8 & 1 & 0.6 & 1.2 & 0.8 & 5.25 & $\mathrm{MH}$ \\
\hline 32 & 1.05 & 0 & 0.9 & 1 & 1.1 & 1.7 & 5.75 & $\mathrm{MH}$ & 78 & 0.85 & 0 & 1 & 0.6 & 1.2 & 1.2 & 4.85 & LH \\
\hline 33 & 1.3 & 0 & 0.9 & 1 & 1.1 & 2 & 6.3 & $\mathrm{HH}$ & 79 & 0.85 & 0 & 1 & 0.6 & 1.5 & 0.8 & 4.75 & LH \\
\hline 34 & 1 & 0 & 0.9 & 1 & 0.8 & 2 & 5.7 & MH & 80 & 0.85 & 0 & 1 & 0.6 & 1.2 & 0.8 & 4.45 & LH \\
\hline 35 & 1 & 0 & 0.9 & 1 & 1.5 & 2 & 6.4 & $\mathrm{HH}$ & 81 & 0.85 & 0.5 & 1 & 0.6 & 1.2 & 1.2 & 5.35 & $\mathrm{MH}$ \\
\hline 36 & 1.2 & 0 & 0.9 & 1 & 1.5 & 2 & 6.6 & $\mathrm{HH}$ & 82 & 0.85 & 0.5 & 1 & 1 & 1.2 & 1.2 & 5.75 & $\mathrm{MH}$ \\
\hline 37 & 0.95 & 0 & 0.9 & 1 & 2 & 2 & 6.85 & $\mathrm{HH}$ & 83 & 0.85 & 0.5 & 1 & 0.6 & 1.2 & 1.2 & 5.35 & $\mathrm{MH}$ \\
\hline 38 & 1 & 0 & 0.9 & 1 & 2 & 1.7 & 6.6 & $\mathrm{HH}$ & 84 & 0.85 & 0.5 & 1 & 0.6 & 1.2 & 1.2 & 5.35 & $\mathrm{MH}$ \\
\hline 39 & 0.7 & 0 & 0.9 & 1 & 2 & 1.7 & 6.3 & $\mathrm{HH}$ & 86 & 0.85 & 0.5 & 1 & 1 & 1.2 & 1.2 & 5.75 & $\mathrm{MH}$ \\
\hline 40 & 1 & 0 & 0.9 & 1 & 2 & 2 & 6.9 & $\mathrm{HH}$ & 85 & 0.85 & 0.5 & 1 & 1 & 1.2 & 1.2 & 5.75 & $\mathrm{MH}$ \\
\hline 41 & 0.7 & 0 & 0.9 & 1 & 2 & 1.7 & 6.3 & $\mathrm{HH}$ & 87 & 0.85 & 0 & 1 & 0.6 & 1.2 & 1.2 & 4.85 & LH \\
\hline 42 & 1 & 0 & 0.9 & 1 & 2 & 1.2 & 6.1 & $\mathrm{HH}$ & 88 & 0.85 & 0 & 1 & 0.6 & 1.2 & 2 & 5.65 & $\mathrm{MH}$ \\
\hline 89 & 0.85 & 0 & 1 & 0.6 & 1.2 & 2 & 5.65 & $\mathrm{MH}$ & 108 & 1.05 & 0 & 0.9 & 1 & 0.8 & 1.7 & 5.45 & $\mathrm{MH}$ \\
\hline 90 & 0.85 & 0 & 1 & 1 & 1.2 & 1.7 & 5.75 & $\mathrm{MH}$ & 109 & 0.9 & 0 & 0.9 & 1 & 1.3 & 1.7 & 5.8 & $\mathrm{MH}$ \\
\hline 91 & 0.85 & 0 & 1 & 1 & 1.3 & 1.7 & 5.85 & $\mathrm{MH}$ & 110 & 1.05 & 0 & 0.9 & 1 & 1.5 & 1.7 & 6.15 & $\mathrm{HH}$ \\
\hline 92 & 0.85 & 0 & 1 & 0.6 & 1.2 & 2 & 5.65 & $\mathrm{MH}$ & 111 & 1.05 & 0 & 0.9 & 1 & 1.5 & 1.7 & 6.15 & $\mathrm{HH}$ \\
\hline 93 & 0.85 & 0 & 1 & 0.6 & 1.2 & 2 & 5.65 & $\mathrm{MH}$ & 112 & 1.05 & 0 & 0.9 & 1 & 1.5 & 1.7 & 6.15 & $\mathrm{HH}$ \\
\hline 94 & 0.85 & 0 & 1 & 1 & 1.5 & 1.7 & 6.05 & $\mathrm{MH}$ & 113 & 1.05 & 0 & 0.9 & 1 & 1.5 & 1.7 & 6.15 & $\mathrm{HH}$ \\
\hline 95 & 0.85 & 0 & 1 & 0.6 & 1.2 & 0.8 & 4.45 & LH & 114 & 1.05 & 0 & 0.9 & 1 & 1.5 & 1.7 & 6.15 & $\mathrm{HH}$ \\
\hline 96 & 0.85 & 0 & 1 & 0.6 & 1.2 & 0.8 & 4.45 & LH & 115 & 1.05 & 0 & 0.9 & 1 & 1.5 & 1.7 & 6.15 & $\mathrm{HH}$ \\
\hline 97 & 0.85 & 0 & 1 & 0.6 & 1.2 & 0.8 & 4.45 & LH & 116 & 0.9 & 0 & 0.9 & 1 & 1.3 & 1.7 & 5.8 & $\mathrm{MH}$ \\
\hline 98 & 0.85 & 0 & 1 & 0.6 & 1.2 & 0.8 & 4.45 & LH & 117 & 0.9 & 0 & 0.9 & 1 & 1.3 & 1.7 & 5.8 & $\mathrm{MH}$ \\
\hline 99 & 0.85 & 0 & 1 & 0.6 & 1.2 & 0.8 & 4.45 & LH & 118 & 1 & 0 & 0.9 & 1 & 2 & 1.7 & 6.6 & $\mathrm{HH}$ \\
\hline 100 & 0.85 & 0 & 1 & 0.6 & 1.2 & 1.2 & 4.85 & LH & 119 & 1 & 0 & 0.9 & 1 & 2 & 1.7 & 6.6 & $\mathrm{HH}$ \\
\hline 101 & 0.85 & 0 & 1 & 0.6 & 1.2 & 1.2 & 4.85 & LH & 120 & 1 & 0 & 0.9 & 1 & 2 & 1.7 & 6.6 & $\mathrm{HH}$ \\
\hline 102 & 0.85 & 0 & 1 & 0.3 & 1.2 & 0.8 & 4.15 & LH & 121 & 1 & 0 & 0.9 & 1 & 1.1 & 2 & 6 & $\mathrm{MH}$ \\
\hline 103 & 0.85 & 0 & 1 & 0.3 & 1.2 & 0.8 & 4.15 & LH & 122 & 1 & 0 & 0.9 & 1 & 0.8 & 2 & 5.7 & $\mathrm{MH}$ \\
\hline 104 & 0.85 & 0 & 1 & 1 & 1.3 & 1.7 & 5.85 & $\mathrm{MH}$ & 123 & 1.6 & 0 & 0.9 & 1 & 1.5 & 1.7 & 6.7 & $\mathrm{HH}$ \\
\hline 105 & 0.85 & 0 & 1 & 1 & 1.5 & 1.7 & 6.05 & $\mathrm{MH}$ & 124 & 0.85 & 0 & 1 & 0.6 & 1.5 & 1.2 & 5.15 & $\mathrm{MH}$ \\
\hline 106 & 1.05 & 0 & 0.9 & 1 & 1.5 & 1.7 & 6.15 & $\mathrm{HH}$ & 125 & 0.85 & 0 & 1 & 1 & 1.5 & 1.2 & 5.55 & $\mathrm{MH}$ \\
\hline 107 & 1.05 & 0 & 0.9 & 1 & 1.2 & 1.7 & 5.85 & MH & & & & & & & & & \\
\hline
\end{tabular}

Note: * HH - High Hazard Zone, MH - Moderate High Hazard Zone, LH - Low Hazard Zone 


\section{Moderate hazard}

Moderate hazard zone has a TEHD value falling between 5.1 and 6.0 (Anbalagan, 1992). This zone covers most of the areas in the northeast and some areas in the south western part of the study area. In total, 38 facets fall within moderate hazard zone which covers around $34 \%$ of the total study area (Fig. 7).

\section{High hazard}

In High Hazard zone TEHD value falls between 6.1 and 7.5 (Anbalagan, 1992). As a result of the geomorphological setting of the study area, most of the facets are in this group. Out of 125 facets, 69 facets fall within high hazard zone, which comprises $54 \%$ of the total study area. A major part of the new road (Fofa to Powerhouse) is constructed in this zone (Fig. 7).

\section{SUMMARY}

The Landslide hazard zonation of the study area, based on the TEHD values, suggests that $54 \%$ of the slopes fall in High Hazard, 34\% in the Moderate hazard and only $12 \%$ of the area falls in Low Hazard zones. These figures clearly indicate that most of the study area falls under High Hazard or Moderate hazard. In fact a major part of the new road (Fofa to Powerhouse) is constructed in High Hazard Zone. This implies that chances of slope failure within this zone are high and the road section might likely be affected by landslide activities. However, a slope may only fail when the driving forces exceed the resisting forces and the orientation of discontinuities is such that they favour sliding, either on single discontinuity or on a wedge formed by two intersecting discontinuities. Moreover, even if slope is potentially unstable, it does not mean that slope is actually going to fail, until or unless there is a triggering factor such as heavy water saturation, earthquake loading or manmade causes such as inadequate agricultural practices or constructional activities.

\section{CONCLUSION}

Gilgel Gibe-II Hydroelectric Project which is one of the major hydropower projects is reaching completion in South-western Ethiopia. From Fofa town to Gilgel Gebe-II powerhouse, a new road has been constructed on an extremely rugged terrain characterized by steep hill slopes and deep valleys. To provide information on the landslide hazard zones present along the new road. The present study has been carried out to delineate the landslide hazard zones in the study area. The landslide hazard evaluation factor rating scheme (LHEF) of Anbalagan's (1992) has been utilized. The LHEF is an empirical approach which is based on past experience gained from the study of causative factors and their impact on landslides with conditions anticipated in the area of study. The LHEF scheme is based on major inherent causative factors such as geology, slope morphometry, relative relief, land use and land cover and ground water conditions which have impacts on the slope stability. The findings of the present study indicate that $54 \%$ of the slopes in the study area fall in High Hazard, 34\% in the Moderate hazard and only $12 \%$ in the Low Hazard. Thus, most of the slopes in the study area falls under High or moderately hazardous zones. Therefore, the chances of slope failures are high in the study area. As a fact a major part of the new road (Fofa to Powerhouse) is constructed in High Hazard Zone. This implies that chances of slope failure within High Hazard Zone are high and the road section within this zone is likely to be affected by landslide activities. Hence, there is a need to conduct more elaborate quantitative slope stability studies within Landslide High Hazard zone identified during the present study. Such a study may identify potential unstable zones along the road side so that suitable remedial measures can be worked out.

\section{ACKNOWLEDGEMENTS}

We are grateful to the Gilgel Gibe-II Hydroelectric project authorities for their kind cooperation. We are thankful to the head and staff of the Department of Earth sciences, Addis Ababa University for extending all kinds of support. We are also thankful to the three referees for giving very useful critical comments and suggestions based on which the overall quality of this paper has been improved.

\section{REFERENCES}

1. Almaz Gezahegn and Tadesse Dessie (1994). A Report on Engineering Geological Studies of the Parts of Blue Nile Gorge (Gohatsion-Dejen), Unpublished Report, Geological Survey of Ethiopia, Addis Ababa, Ethiopia.

2. Anbalagan, R. (1992). Landslide hazard evaluation and zonation mapping in mountainous Terrain. Eng. Geol. 32:269-277. 
3. Anbalagan, R., Sharma, S. and Raghuvanshi, T.K. (1992). Rock mass stability evaluation using modified SMR Approch. In: Proc. $6^{\text {th }}$ Nati. Sympo. on Rock Mechanics, pp. 258-268, Bangalore, India.

4. Barton, N., Lien, R. and Lunde, J. (1974). Engineering classification of rock masses for the design of tunnel support. Rock Mech. 6(4):189-236.

5. Bieniawiski, Z.T. (1989). Engineering Rock Mass Classifications. Wiley, New York, 251 pp.

6. Bieniawiski, Z.T. (1979). The geomechanics classification in rock engineering applications' In: Proc. $4^{\text {th }}$. Cong., Int. Soc. Rock Mech., Vol. 2, pp. 41-48, Montreux, Switzerland, A.A. Balkema, Rotterdam.

7. Berhanu Temesigen, Mohammed Umer and Tesfaye Korme (2001). Natural hazard assessment using GIS and remote sensing methods with particular reference to the landslides in the Wondogenet area, Ethiopia. Phys. Chem. Earth (C) 26(9):665675.

8. Davidson, A. and Rex, D.(1983). Age of volcanism and rifting in south western Ethiopia. Nature 283:657-658.

9. EEPCO (2004). Giigel Gibe II Hydro electric power project Geotechnical report for tunnel alignment. Unpubl. Technical report, Ethiopian Electric Power Corporation (EEPCO) Addis Ababa, Ethiopia, 150 pp.

10. Gebretsidik Eshete (1982). Slope instability Survey in Dessie town. Unpublished Report, Ethiopian Institute of Geological Survey, Addis Ababa, Ethiopia.

11. Getachew Lemmesa, Bayessa Ayele, Sileshi Mamo and Shimelis Ashenafi (2000). Mass movement hazard assessment on Betto and parts of Sawla sub sheet of Goffa District, North Omo Zone, Southern Nations Nationalities and People's Regional State. Unpublished Report, Geological Survey of Ethiopia, Addis Ababa, Ethiopia.

12. Fall, M., Azzam, R. and Noubactep, C. (2006). A multi-method approach to study the stability of natural slopes and landslide susceptibility mapping. Engineering Geology 82:241-263.

13. Henok Woldegiorgis (2008). Landslide hazard zonation mapping in Blue Nile Gorge. Unpublished MSc Thesis, Addis Ababa University, Addis Ababa, Ethiopia.

14. Jemal Saed (2005). Slope stability studies along Gohatsion Dejen Road. Unpublished MSc Thesis, Addis Ababa University, Addis Ababa, Ethiopia.

15. Kazmin, V. and Seife Michael Berhe (1978). Geology and development of the Nazret area, Northern Ethiopian Rift sheet NC37-15, Memoir No. 3, 26 pp.

16. Kefeyalew Terefe (2001). Engineering geological mapping and landslide assessment of Dessie Town. Unpublished MSc Thesis, Addis Ababa University, Addis Ababa, Ethiopia.
17. Lulseged Ayalew and Hiromitsu Yamagishi (2002). Land sliding and landscape development; the case in Northern Ethiopia. In: International Congress of INTERPRAEVENT 2002 in the Pacific Rim, pp. 595-606, Matsumoto, Japan.

18. Lulseged Ayalew (1999). The effect of seasonal rainfall on landslides in the highlands of Ethiopia. Bulletin of Engineering Geology and the Environment 58 (1):9-19.

19. Mesfin Wubshet, Tibebe Mengesha and Kumela Deressa (1994). A report on the engineering geological investigation along proposed alternation route, Blue Nile Gorge. Unpublished Report, Ethiopian Institute of Geological Survey, Addis Ababa, Ethiopia.

20. Pachauri, A.K, and Pant, M. (1991). Landslide hazard mapping based on geological attributes. Engi. geol 32:81-100.

21. Ritter, W. (1879). Die Statik der Tunnelgewolbe. Springer Publishers, Berlin, Germany.

22. Romana, M. (1985). New adjustment ratings for application of Bieniawski Classification to slopes. In: Inte. Sympo. on the Role of Rock Mechanics ISRM, pp. 49-53 Zacatecas, Mexico.

23. Sharma, V.K. (2006). Zonation of landslide hazard for urban planning case study of Nainital town, Kumaon Himalaya, India, IAEG, The Geological Society of London, Paper No.191, pp. 1-6.

24. Shiferaw Ayele (2009). Slope instability and hazard zonation Mapping using remote sensing and GIS technique in Abay Gorge (Gohatsion Dejen), Central Ethiopia. Unpublished MSc Thesis, Addis Ababa University, Addis Ababa, Ethiopia.

25. Terzaghi, K. (1946). Rock defects and loads on tunnel supports. In: Rock Tunneling with Steel Supports, pp. 17-99 (Proctor, R.V. and White, T.L., eds) Commercial Shearing and Stamping Company. Youngstown, $\mathrm{OH}$.

26. Tenalem Ayenew and Barbieri, G. (2004). Inventory of landslides and susceptibility mapping in the Dessie area, Northern Ethiopia. Engineering Geology J. 77:1-15.

27. Tierrcelin, J.J., Taieb, M., and Faure, H. (1980). Continental sedimentary basins and volcanotectonic evolution of the Afar Rift. Accad. Naz. Lincei 47:491-504.

28. Wickham, G.E., Tiedemann, H.R. and Skinner, E.H. (1972). Support determination based on geologic predictions. In: Proc. North American Rapid Excav. Tunneling Conf., Chicago, pp. 43-64 (Lane, K.S. and Garfield, L.A., eds) Soc. Min. Engrs, Am. Inst. Min. Metall. Petrolm Engrs, New York.

29. Yodit Teferi (2005). Evaluation of land degradation and landslide using integrated GIS and remote sensing approach around Sodo-Shone Area, Southern Ethiopia. Unpublished MSc Thesis, Addis Ababa University, Addis Ababa, Ethiopia. 